\title{
HUBUNGAN TINGKAT KEPERCAYAAN DIRI DENGAN JERAWAT (ACNE VULGARIS) PADA REMAJA KELAS X-XII IPA SMAN 9 BINSUS MANADO
}

\author{
${ }^{1}$ Feggy Esterlita Irene Tampi \\ ${ }^{2}$ Lydia David \\ ${ }^{3}$ H. Opod \\ ${ }^{1}$ Kandidat Skripsi Kedokteran Universitas Sam Ratulangi Manado \\ ${ }^{2}$ Bagian Psikologi Fakultas Kedokteran Universitas Sam Ratulangi Manado \\ Email: feggytampi@yahoo.com
}

\begin{abstract}
Acne is a chronic inflammatory disease of the pilosebaceous follicles which generally occurs in adolescence and can heal itself. Teenagers who have acne problems often have problems associated with self-confidence. Self-confidence is an attitude or feeling confident of his own abilities. Individuals who have the self-confidence have a positive feelings toward him. Individuals who do not believe themselves to have shy behavior and cannot adjust to the environment. This study aims to assess the scientific self-confidence level correlation with acne in adolescents classes X-XII Science at SMAN 9 Binsus Manado. This research uses a cross-sectional study with a sample of 130 people. The results showed the value of correlation coefficient are -0.144 where this value showed a negative correlation between self-confidence with acne and the value of correlation coefficient are 0.144 , the correlation between two variables is very weak with significance value at $0.103>0.05$, which means there is no significant correlation between self-confidence with acne. So it can be concluded that this hypothesis is rejected, meaning that there is no significant correlation between self-confidence with acne.
\end{abstract}

Keywords: Acne, Self-confidence, Adolescents

\begin{abstract}
Abstrak: Jerawat adalah penyakit peradangan menahun folikel pilosebasea yang umumnya terjadi pada masa remaja dan dapat sembuh sendiri. Remaja yang mengalami masalah jerawat seringkali mempunyai masalah yang berkaitan dengan kepercayaan diri. Kepercayaan diri merupakan suatu sikap atau perasaan yakin atas kemampuan sendiri. Individu yang mempunyai kepercayaan diri memiliki perasaan positif terhadap dirinya. Individu yang tidak percaya diri mempunyai perilaku malu dan tidak bisa menyesuaikan diri dengan lingkungan. Penelitian ini bertujuan untuk mengkaji secara ilmiah hubungan tingkat kepercayaan diri dengan jerawat pada remaja kelas X-XII IPA SMAN 9 Binsus Manado. Penelitian ini menggunakan jenis penelitian rancangan cross sectional dengan jumlah sampel 130 orang. Hasil penelitian menunjukkan nilai koefisien korelasi sebesar -0,144 dimana nilai ini menujukkan hubungan negatif antara kepercayaan diri dengan jerawat dan dari nilai koefisien korelasi 0,144 maka hubungan antara kedua variabel sangat lemah dengan nilai signifikansi 0,103 > 0,05 yang berarti tidak terdapat hubungan signifikan antara kepercayaan diri dengan jerawat. Jadi dapat disimpulkan bahwa hipotesis dalam penelitian ini ditolak, artinya tidak terdapat hubungan signifikan antara kepercayaan diri dengan jerawat.
\end{abstract}

Kata Kunci: Jerawat, Kepercayaan diri, Remaja 
Jerawat atau acne vulgaris adalah penyakit kulit yang paling umum, yang mempengaruhi hampir $80 \%$ orang pada usia 11 sampai 30 tahun. ${ }^{1}$ Penyakit ini tidak fatal, tetapi cukup merisaukan karena berhubungan dengan menurunkan kepercayaan diri akibat berkurangnya keindahan wajah penderita. ${ }^{2}$ Penyebab jerawat sangat banyak (multifaktorial), antara lain genetik, endokrin, faktor makanan, keaktifan dari kelenjar sebasea, faktor psikis, musim, infeksi bakteri (Propionibacterium acnes), kosmetika dan bahan kimia lainnya. $^{3}$

Insiden jerawat $80-100 \%$ pada usia dewasa muda, yaitu umur 14-17 tahun pada wanita, dan 16-19 tahun pada pria. Prevalensi tertinggi yaitu pada umur 16-17 tahun, dimana pada wanita berkisar 8385\% dan pada pria berkisar 95-100\%. Dari survey di kawasan Asia Tenggara, terdapat 40-80\% kasus jerawat sedangkan di Indonesia, catatan kelompok studi dermatologi kosmetika Indonesia, menunjukkan terdapat $60 \%$ penderita jerawat pada tahun 2006 dan 80\% pada tahun 2007. ${ }^{4}$ Jerawat seringkali dihubungkan dengan kondisi tubuh, baik pada saat stress karena banyak masalah, atau dapat pula sebaliknya pada saat sedang sangat berbahagia. Pada waktu pubertas terdapat kenaikan dari hormon androgen yang beredar dalam darah yang dapat menyebabkan hyperplasia dan hipertrofi dari glandula sebasea sehingga tidak heran jika angka kejadian jerawat paling tinggi pada usia remaja. ${ }^{1}$

Kehidupan sebagai remaja merupakan salah satu periode dalam rentang kehidupan manusia. Masa remaja adalah masa peralihan dari anak-anak ke dewasa, bukan hanya dalam artian psikologis tetapi juga fisik. ${ }^{5}$ Permasalahan akibat perubahan fisik banyak dirasakan oleh remaja ketika mereka mengalami pubertas. Salah satu perubahan fisik yang sering menjadi permasalahan pada masa remaja adalah jerawat. Masalah ini memberi kesan psikologis yang buruk pada remaja, terutama remaja dalam rentang usia sekolah. Remaja yang mengalami masalah jerawat sering kali mempunyai masalah yang berkaitan dengan kepercayaan diri. ${ }^{6}$

Modal dasar untuk pengembangan dalam aktualisasi diri (eksplorasi segala kemampuan diri) adalah kepercayaan diri, yaitu suatu aspek kepribadian manusia yang berfungsi penting untuk mengaktualisasikan potensi yang dimilikinya dan sangat dibutuhkan untuk memperoleh kesuksesan dalam kehidupan sehari-hari. ${ }^{7}$ Kepercayaan diri merupakan kunci motivasi diri. Individu tidak dapat menjalani hidup dengan baik tanpa kepercayaan diri. Setiap individu akan membutuhkan kepercayaan diri setiap harinya dalam berbagai hal. Tingkat kepercayaan diri yang baik memudahkan dalam pengambilan keputusan dan melancarkan jalan untuk mendapatkan teman, membangun hubungan, dan membantu individu mempertahankan kesuksesan. Individu yang mempunyai kepercayaan diri memiliki perasaan positif terhadap dirinya, punya keyakinan yang kuat atas dirinya dan punya pengetahuan akurat terhadap kemampuan yang dimiliki. Begitu besar fungsi dan peranan kepercayaan diri pada kehidupan individu. Tanpa adanya rasa percaya diri yang tertanam dengan kuat di dalam jiwa individu, pesimisme dan rasa rendah diri akan dengan mudah menguasai dirinya. Tanpa dibekali kepercayaan diri yang mantap sejak dini, maka individu akan tumbuh menjadi pribadi yang lemah. ${ }^{8}$

Dampak yang muncul akibat perilaku yang tidak percaya diri, yaitu terhambatnya perkembangan individu yang mempunyai perilaku malu, semakin tidak terasahnya kemampuan sosial individu, tidak bisa menyesuaikan diri dengan lingkungan, kurang informasi dan pergaulan, kurang pengalaman, menimbulkan kesulitan belajar apabila terjadi pada anak usia sekolah. ${ }^{9}$ 
Data statistik dari departemen kesehatan, pendidikan dan kesejahteraan Amerika tahun 1976, menyatakan lebih dari $40-80 \%$ remaja laki-laki dan perempuan usia 12-17 tahun merasa "agak" atau "sangat terganggu” oleh kondisi jerawat. Data tersebut juga menunjukkan bagaimana meningkatnya keprihatinan remaja laki-laki dan perempuan pada jerawat. ${ }^{10}$ Dalam penelitian Asri Tambunan mengenai hubungan kulit wajah berjerawat dengan rasa percaya diri pada siswa kelas XI SMAN 1 Purba kabupaten Simalungun berada pada kategori sedang yang menunjukkan bahwa kulit wajah berjerawat yang dialami oleh siswa berhubungan dengan kurangnya rasa percaya diri yang dimiliki oleh siswa tersebut. $^{11}$

Dengan adanya masalah tersebut maka dilakukan penelitian dengan tujuan untuk mengkaji secara ilmiah bagaimana hubungan tingkat kepercayaan diri dengan jerawat pada remaja kelas X-XII IPA SMAN 9 Binsus Manado.

\section{METODE PENELITIAN}

Metode penelitian yang di gunakan adalah penelitian korelasional dengan pendekatan Cross Sectional. Penelitian ini dilaksanakan pada bulan November sampai Desember 2015 dan dilaksanakan di SMAN 9 Binsus Manado. Populasi dalam penelitian ini adalah siswa-siswi kelas $\mathrm{X}$ XII IPA yang berjerawat berjumlah 130 orang. Pengambilan sampel pada penelitian ini adalah total sampling dimana jumlah sampel sesuai dengan jumlah total populasi yaitu 130 orang yang berjerawat yang termasuk dalam kriteria inklusi. Kriteria inklusi seperti siswa-siswi kelas X-XII IPA SMAN 9 Binsus Manado, siswa-siswi yang telah bersedia menjadi sampel, dan siswa-siswi yang berjerawat. Pembuktian hipotesis penelitian menggunakan teknik korelasi Rank Spearman menggunakan program SPSS 20.

\section{HASIL PENELITIAN}

Pada penelitian ini jumlah responden yang mengalami gradasi jerawat ringan berjumlah 77 orang (59,2\%), sedangkan gradasi jerawat sedang berjumlah 43 orang $(33,1 \%)$ dan gradasi jerawat berat sebanyak 10 orang (7,7\%). Responden paling banyak berada pada gradasi jerawat ringan. Dalam penelitian ini tingkat kepercayaan diri yang sangat rendah dan rendah tidak ada responden. Sementara responden dengan tingkat kepercayaan diri sedang sebanyak 7 orang (5,4\%), responden dengan tingkat kepercayaan diri tinggi sebanyak 55 orang (42,3\%) dan responden dengan kepercayaan diri sangat tinggi sebanyak 68 orang (52,3\%).

Berdasarkan hasil penelitian, pada gradasi jerawat berat dengan kepercayaan diri sedang sebanyak 3 orang, sementara pada gradasi sedang dengan kepercayaan diri sedang sebanyak 2 orang dan pada gradasi ringan dengan kepercayaan diri sedang sebanyak 2 orang. Pada gradasi berat dengan kepercayaan diri tinggi sebanayak 3 orang, sementara pada gradasi sedang dengan kepercayaan diri tinggi sebanyak 21 orang dan pada gradasi ringan dengan kepercayaan diri tinggi sebanyak 31 orang. Pada gradasi berat dengan kepercayaan diri sangat tinggi berjumlah 4 orang, sementara pada gradasi sedang dengan kepercayaan diri sangat tinggi sebanyak 20 orang dan pada gradasi ringan dengan kepercayaan diri sangat tinggi sebanyak 44 orang.

Tabel 1.

Distribusi Responden Berdasarkan Gradasi Jerawat

\begin{tabular}{ccccc}
\hline No & Keterangan & Bobot & Jumlah & Persentase \\
\hline $\mathbf{1}$ & Ringan & 1 & 77 Orang & $59,2 \%$ \\
$\mathbf{2}$ & Sedang & 2 & 43 Orang & $33.1 \%$ \\
$\mathbf{3}$ & Berat & 3 & 10 Orang & $7.7 \%$ \\
\hline & Total & & $\mathbf{1 3 0}$ Orang & $\mathbf{1 0 0 \%}$ \\
\hline
\end{tabular}


Tabel 2. Distribusi Responden Berdasarkan Tingkat Kepercayaan Diri

\begin{tabular}{|c|c|c|c|c|}
\hline No & Kategori & Range & Jumlah & Persentase \\
\hline 1 & Sangat Rendah & $28-44,8$ & - & - \\
\hline 2 & Rendah & $44,8-61,6$ & - & - \\
\hline 3 & Sedang & $61,6-78,4$ & 7 Orang & $5,4 \%$ \\
\hline 4 & Tinggi & 78,4 - 95,2 & 55 Orang & $42,3 \%$ \\
\hline 5 & Sangat Tinggi & $95,2-112$ & 68 Orang & $52,3 \%$ \\
\hline \multicolumn{3}{|c|}{ Total } & 130 Orang & $100 \%$ \\
\hline
\end{tabular}

Tabel 3. Distribusi Responden Berdasarkan Tingkat Kepercayaan Diri dan Gradasi Jerawat

\begin{tabular}{cccccc}
\hline \multirow{2}{*}{ No } & \multirow{2}{*}{ Kepercayaan Diri } & \multicolumn{3}{c}{ Gradasi Jerawat } & \multirow{2}{*}{ Total } \\
\cline { 3 - 5 } & Berat & Sedang & Ringan & \\
\hline 1 & Sangat Rendah & - & - & - & - \\
2 & Rendah & - & - & - & - \\
3 & Sedang & 3 Orang & 2 Orang & 2 Orang & 7 Orang \\
4 & Tinggi & 3 Orang & 21 Orang & 31 Orang & 55 Orang \\
5 & Sangat Tinggi & 4 Orang & 20 Orang & 44 Orang & 68 Orang \\
\hline & Jumlah & 10 Orang & 43 Orang & 77 Orang & $\mathbf{1 3 0}$ Orang \\
\hline
\end{tabular}

Tabel 4. Pengujian Hubungan Antara Variabel Kepercayaan Diri dengan Variabel Jerawat

\begin{tabular}{|c|c|c|c|c|}
\hline & & & $\begin{array}{c}\text { Kepercayaan } \\
\text { Diri }\end{array}$ & $\begin{array}{c}\text { Graradasi } \\
\text { Jerawat }\end{array}$ \\
\hline \multirow{6}{*}{ Spearman's rho } & \multirow{3}{*}{ Kepercayaan Diri } & Correlation Coefficient & 1.000 & -0.144 \\
\hline & & . (2-tailed) & . & 0.103 \\
\hline & & \multirow{4}{*}{$\begin{array}{l}\text { Correlation Coefficient } \\
\text {. (2-tailed) }\end{array}$} & 130 & 130 \\
\hline & \multirow{3}{*}{ Graadasi Jerawat } & & -0.144 & 1.000 \\
\hline & & & 0.103 & . \\
\hline & & & 130 & 130 \\
\hline
\end{tabular}

Dapat dilihat pada tabel 4 nilai koefisien korelasi sebesar -0,144 yang menujukkan hubungan negatif antara kepercayaan diri dengan jerawat dan nilai koefisien korelasi 0,144 menunjukkan keeratan korelasi antara kedua variabel sangat lemah dengan kriteria 0,00 0,20. Nilai signifikansi 0,103 >0,05 (Alpha/Taraf nyata) yang berarti tidak terdapat hubungan signifikan antara kepercayaan diri dengan jerawat.

\section{PEMBAHASAN}

Berdasarkan hasil analisis data diperoleh data tentang kepercayaan diri dimana tingkat kepercayaan diri terbagi menjadi lima kategori. Kategori kepercayaan diri sangat tinggi 68 orang (52,3\%), tinggi 55 orang (42,3\%), sedang 7 orang $(5,4 \%)$, sementara tingkat

kepercayaan diri rendah dan sangat rendah tidak ada responden, sehingga dapat disimpulkan bahwa tingkat kepercayaan diri siswa kelas X-XII IPA yang berjerawat di SMAN 9 Binsus Manado adalah sangat tinggi. Hal ini dipengaruhi oleh beberapa 
faktor sehingga terbentuklah individu yang memiliki kepercayaan diri yang sangat tinggi. Akan tetapi setiap faktor tersebut berbeda di setiap individu dalam membentuk kepercayaan diri mereka. Faktor-faktor yang dapat mempengaruhi kepercayaan diri yaitu faktor fisik, faktor mental dan faktor sosial. Faktor-faktor inilah yang membentuk kepercayaan diri sehingga ciri-ciri kepercayaan diri dari setiap individu terbentuk. Individu yang memiliki tingkat kepercayaan diri yang tinggi dapat dipengaruhi oleh beberapa faktor yaitu berhasil di dalam domaindomain diri yang penting, adanya dukungan emosional dan persetujuan sosial dalam bentuk konfirmasi dari orang lain seperti dukungan dari orang tua dan teman sebaya, memiliki prestasi di sekolah dan mampu menghadapi suatu masalah dan berusaha untuk mengatasinya. Perilaku ini menghasilkan suatu evaluasi diri yang menyenangkan dan dapat meningkatkan rasa percaya diri. ${ }^{12}$

Penelitian yang dilakukan oleh Adams dkk menemukan bahwa penampilan fisik merupakan suatu kotributor yang sangat berpengaruh pada rasa percaya diri remaja. Pada penelitian Harter, penampilan fisik secara konsisten berkolerasi paling kuat dengan rasa percaya diri secara umum, yang baru kemudian diikuti oleh penerimaan sosial teman sebaya. ${ }^{12}$

Dalam penelitian ini peningkatan kepercayaan diri remaja kemungkinan dipengaruhi oleh faktor pola asuh dari orang tua seperti pada penelitian Coopersmith mengenai hubungan orang tua dan anak dengan rasa percaya diri, terdapat suatu alat ukur rasa percaya diri yang diberikan kepada anak laki-laki dan kemudian anak laki-laki beserta ibunya diwawancara mengenai hubungan keluarga mereka. Berdasarkan pengukuran tersebut, berikut ini adalah faktor-faktor dari orang tua yang berhubungan dengan tingkat rasa percaya diri yang tinggi dari anak laki-laki tersebut:
1. Ekspresi rasa kasih sayang

2. Perhatian terhadap masalah yang dihadapi oleh anak

3. Keharmonisan dirumah

4. Partisipasi dalam aktivitas bersama keluarga

5. Kesedian untuk memberikan pertolongan yang kompeten dan terarah kepada anak ketika mereka membutuhkannya

6. Menetapkan peraturan yang jelas dan adil

7. Mematuhi peraturan-peraturan tersebut

8. Memberikan kebebasan pada anak dengan batas-batas yang telah ditentukan

Pola asuh dari orang tua terbukti sebagai faktor penentu yang penting bagi rasa percaya diri remaja, berdasarkan data penelitian yang menunjukkan adanya korelasi. $^{12}$

Pada penelitan Harter menunjukkan bahwa dukungan dari teman sebaya lebih berpengaruh terhadap tingkat rasa percaya diri remaja. Terdapat dua jenis dukungan teman sebaya yang diteliti, yaitu dukungan teman sekelas dan dukungan teman akrab. Dukungan dari teman satu kelas berpengaruh lebih kuat terhadap rasa percaya diri remaja dibandingkan dengan dukungan teman akrab. Hal ini bisa saja terjadi mengingat, teman akrab selalu memberikan dukungan yang dibutuhkan, sehingga dukungan tersebut tidak dianggap oleh remaja sebagai sesuatu yang meningkatkan percaya diri mereka, karena remaja pada saat-saat tertentu membutuhkan sumber dukungan yang lebih obyektif untuk membenarkan rasa percaya dirinya. ${ }^{12}$

Berdasarkan hasil uji korelasi Rank Spearman antara kepercayaan diri dengan jerawat pada siswa kelas X-XII IPA di SMAN 9 Binsus Manado didapatkan hasil nilai koefisien korelasi sebesar -0,144 dimana nilai ini menujukkan hubungan negatif dan dari nilai koefisien korelasi 0,144 menunjukkan keeratan hubungan antara kedua variabel sangat lemah dengan 
nilai signifikansi $0,103>0,05$ (Alpha/Taraf nyata) yang berarti tidak terdapat hubungan signifikan antara kepercayaan diri dengan jerawat.

Jadi dapat disimpulkan bahwa hipotesis dalam penelitian ini telah terbukti, artinya tidak terdapat hubungan signifikan antara kepercayaan diri dengan jerawat.

\section{KESIMPULAN}

Berdasarkan hasil uji korelasi antara kepercayaan diri dengan jerawat menunjukkan nilai koefisien korelasi sebesar -0,144 dan nilai signifikansi 0,103 $>0,05$ dengan keeratan korelasi sangat lemah. Hal ini menunjukkan bahwa tidak terdapat hubungan signifikan antara kepercayaan diri dengan jerawat pada remaja kelas X-XII IPA SMAN 9 Binsus Manado.

\section{SARAN}

Saran untuk penelitian selanjutnya diharapkan sampel dalam penelitian ini lebih spesifik pada gradasi jerawat yang berat dengan sampel yang lebih besar dan melakukan penelitian dengan faktor-faktor penyebab lainnya yang dapat mempengaruhi kepercayaan diri remaja untuk mendapatkan hasil yang lebih akurat.

\section{UCAPAN TERIMA KASIH}

Ucapan terima kasih disampaikan kepada dr. Herdy Munayang, MA, Cicilia Pali, M.Psi dan kepada semua pihak baik secara langsung maupun tidak lansung telah menumbuhkan ide atau gagasan dalam pemikiran penulis sehingga dapat menyelesaikan artikel ini.

\section{DAFTAR PUSTAKA}

1. Leyden James J. M.D. Therapy for acne vulgaris. New England Journal Medicine. 1997; 336: 1156-1162.

2. Efendi Zukesti. Peranan kulit dalam mengatasi terjadinya acne vulgaris.
Fakultas Kedokteran Universitas Sumatera Utara; 2003.

3. Kim Jenny. Acne vaccines: therapeutic option for the treatment of acne vulgaris. Journal of Investigate Dermatology. 2008; 128: 2353-2354.

4. Andy. Pengetahuan dan sikap remaja terhadap jerawat. Fakultas Kedokteran Universitas Sumatera Utara; 2009.

5. Lilis Suryani, Syahniar, Zikra. Penyesuaian diri pada masa pubertas. Jurnal ilmiah konseling. 2013; 2:136140.

6. Deri Anggraini. Hubungan gambaran diri dengan interaksi sosial pada remaja yang berjerawat. Fakultas Keperawatan Universitas Andalas; 2012.

7. Efa Wahyuni. Hubungan persepsi tentang jerawat dengan kepercayaan diri remaja akhir.Fakultas Psikologi Universitas Islam Negeri Syarif Hidayatullah; 2007.

8. Septri Rahayu Purwanti. Mengatasi masalah kepercayaan diri siswa melalui layanan konseling kelompok. Fakultas Ilmu Pendidikan Universitas Negeri Semarang; 2013.

9. Supriyo. Studi Kasus bimbingan Konseling. Semarang: CV. Nieuw Setapak; 2008.

10. Hurlock Elizabeth. B. Psikologi perkembangan suatu pendekatan sepanjang rentang kehidupan. Edisi ke5. Jakarta: Erlangga; 1990.

11. Asri Tambunan, Rohana Aritonang. Hubungan kulit wajah berjerawat dengan rasa percaya diri pada siswa kelas XI SMAN 1 Purba kabupaten Simalungun. Universitas Negeri Medan; 2012.

12. John W. Santrock. Perkembangan sosial, emosional dan kepribadian. In: Wisnu C. Kristiaji, Yati Sumiharti. Adolescene perkembangan remaja. Edisi ke-6. Jakarta: Erlangga; 2003. h. 336-339. 